\title{
Inactivation of Vibrio parahaemolyticus by Aqueous Ozone ${ }^{\text {[S }}$
}

\author{
Lifang Feng, Kuo Zhang, Mengsha Gao, Chunwei Shi, Caiyun Ge, Daofeng Qu, Junli Zhu, Yugang Shi, and \\ Jianzhong Han *
}

School of Food Science and Biotechnology, Zhejiang Gongshang University, Hangzhou 310018, P.R. China

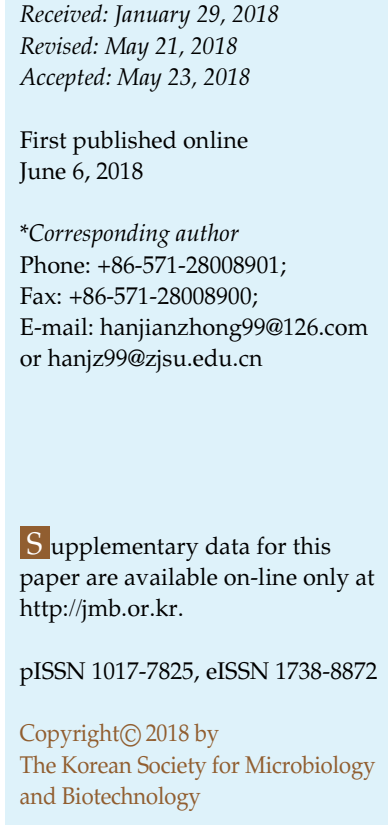

$\mathrm{S}$ upplementary data for this paper are available on-line only at http://jmb.or.kr.

pISSN 1017-7825, eISSN 1738-8872

Copyright(C) 2018 by

The Korean Society for Microbiology and Biotechnology

\begin{abstract}
Vibrio parahaemolyticus contamination causes serious foodborne illness and has become a global health problem. As a disinfectant, aqueous ozone can effectively kill a number of bacteria, viruses, parasites, and other microorganisms. In this study, three factors, namely, the aqueous ozone concentration, the exposure time, and the bacterial density, were analyzed by response surface methodology, and the aqueous ozone concentration was the most influential factor in the sterilization ratio. Under low aqueous ozone concentrations (less than $0.125 \mathrm{mg} / \mathrm{l}$ ), the bacterial cell membranes remained intact, and the ozone was detoxified by intracellular antioxidant enzymes (e.g., superoxide dismutase and catalase). Under high aqueous ozone concentrations (more than $1 \mathrm{mg} / \mathrm{l}$ ), cell membranes were damaged by the degree of peripheral electronegativity at the cell surface and the concentration of lactate dehydrogenase released into the extracellular space, and the ultrastructures of the cells were confirmed by transmission electron microscopy. Aqueous ozone penetrated the cells through leaking membranes, inactivated the enzymes, inhibited almost all the genes, and degraded the genetic materials of gDNA and total RNA, which eventually led to cell death.
\end{abstract}

Keywords: Vibrio parahaemolyticus, aqueous ozone, response surface methodology, transcriptome, inactivation

\section{Introduction}

With the increased consumption of raw seafood in recent years, reports of foodborne illnesses have also gradually increased. Bacterial contamination is the primary hazard, especially pathogenic Vibrio species [1]. Vibrio parahaemolyticus is widely present in shallow seawater and is attached to the body surfaces of some marine crustaceans, mollusks, and other aquatic organisms, where it grows and reproduces. In most environmental samples, $V$. parahaemolyticus does not contain thermostable direct hemolysin and thermostable direct hemolysin-related hemolysin, which are two virulence factors that are harmful to humans [2]. However, a small number of $V$. parahaemolyticus bacteria that carry these factors are pathogenic and can cause nausea, vomiting, abdominal pain, diarrhea, fever, and other symptoms of acute gastroenteritis. These cases primarily occur when people consume contaminated seafood. In particular, in a patient who already has significant health problems, this infection may cause dehydration, shock, coma, and even death $[3,4]$. Therefore, it is critically important to kill or inactivate $V$. parahaemolyticus in edible raw seafood.

Ozone is unstable in water. It will produce a single atom of oxygen, hydroxyl radicals, and other strong oxidants whose oxidation potential is weaker than fluorine but stronger than chlorine. Aqueous ozone can kill or inactivate bacteria, fungi, protozoa, viruses (including hepatitis A and B viruses, human immunodeficiency virus), and other organisms in surface ocean water and food [5]. The bactericidal effect of aqueous ozone is 600-3,000 times greater than that for the same concentration of chlorine [6]. Highly concentrated aqueous ozone obtained by electrolysis does not contain toxic nitrogen oxides and other byproducts. The US Food and Drug Administration has ruled that ozone can be safely used as a fungicide in food production, and the US Environmental Protection Agency has also agreed to the use of ozone as a disinfectant [7]. Currently, ozone is considered as a good, safe food 
preservative and has been widely used in factories to sterilize frozen seafood before packaging [8]. Ozone can also be used to sterilize and disinfect cold storage facilities, processing plant equipment, air, household disinfection cabinet [6], drinking water and wastewater [9, 10], fruits and juice [11, 12], and vegetables [13]. Ozone tolerance varies among microorganisms. Susceptibility to ozone sterilization is related to the type of microorganism [10], its microbial growth period and density [14], the ozone concentration and stress response [15], and other factors [16]. At present, Escherichia coli is the primary model organism used to study the mechanism of ozone sterilization [15]. Ozone and its decomposition products increase the permeability of the lipid bilayer in bacterial cell membranes and decrease their integrity [17]. These compounds then react with enzymes, DNA, and RNA, causing the cell contents to leak through the permeable cell membranes [18-20]. This is the primary process underlying E.coli sterilization.

In this study, V. parahaemolyticus was used to study the effectiveness of aqueous ozone at various concentrations and stress times, and against different bacterial densities. Response surface experiments were used to analyze the effects of the concentration and exposure time of the aqueous ozone solutions and the bacterial density on the survival ratio. Moreover, cell changes were also examined by measuring the enzyme activity, by transmission electron microscopy, and by RNA-Seq technology when exposing the cell to different concentrations of aqueous ozone. These experiments were designed to discern the possible mechanism by which aqueous ozone kills the foodborne pathogen $V$. parahaemolyticus and to provide a theoretical basis for the use of aqueous ozone as a disinfectant in food production facilities and other environments.

\section{Materials and Methods}

\section{Production Growth Curve of V. parahaemolyticus}

$V$. parahaemolyticus strain ATCC 17802 was obtained from the Chinese General Microbiological Culture Collection Center as previously reported [21, 22]. It was grown in Luria-Bertani broth at $37^{\circ} \mathrm{C}$ for $18-22 \mathrm{~h}$. To isolate a single $V$. parahaemolyticus cell, a loop of culture containing the bacteria was spread onto the surface of a thiosulfate-citrate-bile salt-sucrose (Qingdao Hope Bio-Technology Co., Ltd., China) agar plate, which was incubated at $37^{\circ} \mathrm{C}$ for $18-24 \mathrm{~h}$. Large round green translucent colonies were selected from the agar using a loop, and they were then incubated in alkaline peptone water with shaking at $150 \mathrm{rpm}$ for $18-20 \mathrm{~h}$ at $37^{\circ} \mathrm{C}[23]$.

To produce growth curves, $1 \mathrm{ml}$ of culture was re-incubated in
$200 \mathrm{ml}$ of alkaline peptone water with shaking at $150 \mathrm{rpm}$ and $37^{\circ} \mathrm{C}$. Cells were collected at a series of growth stages, and their densities were measured using an Ultrospec $2100 \mathrm{UN} /$ Visible spectrophotometer (Amersham Biosciences, USA) at $\mathrm{OD}_{600}$. Moreover, serial decimal dilutions of cells at different growth stages as measured by ultraviolet spectrophotometry were also prepared, and $1 \mathrm{ml}$ of each dilution was pipetted into an empty sterile petri dish. Subsequently, approximately $20 \mathrm{ml}$ of melted plate count agar (Qingdao Hope Bio-Technology Co., Ltd., China), which had been cooled in a water bath at $46^{\circ} \mathrm{C}$, was poured into the dish, and it was then mixed thoroughly by gentle tilting and swirling. Twenty minutes later, the dishes were turned up-sidedown and incubated at $37^{\circ} \mathrm{C}$ for $18-24 \mathrm{~h}$. Finally, the total colony forming units were considered as the total viable counts (TVC) [24].

\section{Generation and Measurement of Aqueous Ozone}

The aqueous ozone was generated by a high-concentration Ozone Generator (QD-OS-S-300L; Guangzhou Jia Huan Ozone Electric Appliance Co., Ltd., China) at ambient temperatures ranging from 12 to $15^{\circ} \mathrm{C}$, because this temperature range has strong inactivation effects against $E$. coli [15]. The concentration of dissolved aqueous ozone was measured by iodometry. We added $0.071 \mathrm{~g}$ of $\mathrm{KIO}_{3}$ and $1.5 \mathrm{~g}$ of $\mathrm{KI}$ to $50 \mathrm{ml}$ of water in a $250 \mathrm{ml}$ conical flask, and then we added another $50 \mathrm{ml}$ of water. After mixing, $10 \mathrm{ml}$ of acetic acid was added. The resulting iodine was titrated with $0.1 \mathrm{~mol} / 1$ of sodium thiosulfate until the yellow solution almost disappeared. Sodium thiosulfate was a suitable neutralizer to stop the aqueous ozone reaction without affecting the growth of $V$. parahaemolyticus (Table S1). Furthermore, $1 \mathrm{ml}$ of starch solution $(0.5 \%(\mathrm{w} / \mathrm{v}))$ was added as an indicator, and the $0.1 \mathrm{~mol} / \mathrm{l}$ sodium thiosulfate titration was continued when the blue solution disappeared at just the right time [25].

\section{Analysis and Optimization of the Sterilization Ratio of Aqueous Ozone by Response Surface Methodology}

To analyze the influence of the aqueous ozone concentration on the sterilization ratio, $1 \mathrm{ml}$ of cell cultures with densities of $10^{8} \mathrm{CFU} / \mathrm{ml}$ each were mixed with $99 \mathrm{ml}$ of aqueous ozone at concentrations of $0.0625,0.125,0.25,0.5,1.0$, and $2 \mathrm{mg} / \mathrm{l}$. One minute later, $0.1 \mathrm{~mol} / 1$ of sodium thiosulfate was added to terminate the reaction, and the viable cell number was measured by counting the TVC.

To analyze the influence of the cell density on the sterilization ratio, $1 \mathrm{ml}$ of cell cultures with different densities $\left(10^{6}, 10^{8}\right.$, and $10^{10} \mathrm{CFU} / \mathrm{ml}$ ) were mixed with $99 \mathrm{ml}$ of aqueous ozone at a concentration of $1.0 \mathrm{mg} / \mathrm{l}$. The reaction was also terminated by sodium thiosulfate after $1 \mathrm{~min}$, and the viable cell number was measured by counting the TVC.

The aqueous ozone exposure time is also an important factor that affects the sterilization ratio. One milliliter of cell cultures with $10^{8} \mathrm{CFU} / \mathrm{ml}$ was mixed with $99 \mathrm{ml}$ of aqueous ozone at a concentration of $1.0 \mathrm{mg} / \mathrm{l}$. Bacterial samples were exposed for 10 , 
$20,40,80,160$, or $320 \mathrm{sec}$, and their viable cell numbers were measured by counting the TVC. The cells without aqueous ozone treatment were the control. The sterilization ratio was calculated using the following formula:

Sterilization ratio $(\%)=\frac{\text { TVC of control }- \text { TVC of treatment }}{\text { TVC of control }} \times 100 \%$

Based on single-factor analysis, the highest and lowest values of aqueous ozone concentrations, bacterial density, and exposure time were determined individually. These three factors (the aqueous ozone concentration, bacterial density, and exposure time) were then set as independent variables, and the sterilization ratio was analyzed using Design-Expert software 7.0.0 [26].

\section{Measurement of the Zeta Potential of the Cell Surface}

Cell cultures $\left(10^{8} \mathrm{CFU} / \mathrm{ml} ; 1 \mathrm{ml}\right)$ were mixed with $99 \mathrm{ml}$ of aqueous ozone at concentrations of $0.0625,0.125,0.25,0.5,1.0$, and $1.2 \mathrm{mg} / \mathrm{l}$ for $1 \mathrm{~min}$ each. After the reactions were terminated by sodium thiosulfate, the samples were centrifuged and resuspended in stroke-physiological saline solution. They were then washed and resuspended in $1 \mathrm{M} \mathrm{KNO}_{3}(\mathrm{pH}$ 6.2) twice. The zeta potential of the suspended cells was measured using a Zetasizer Nano device (Malvern, UK) [27].

\section{Measurement of Enzymatic Activity}

The lactate dehydrogenase ( $\mathrm{LDH}$ ) content can be used to determine the permeability of cell membranes. As the method used to measure the zeta potential, the cell pellets were exposed to aqueous ozone and were subsequently disrupted ultrasonically. The LDH content was then measured using an LDH activity assay kit (Nanjing Jiancheng Bioengineering Institute, China). Cells that were neither treated with aqueous ozone nor ultrasonically processed were used as the spontaneous group. Cells that were lysed directly by ultrasound were set as the maximum LDH released group. The damage ratio of the cell membrane was expressed by the following equation:

Damage ratio $(\%)=\frac{\text { Treatment LDH-Spontaneous LDH }}{\text { Max LDH-Spontaneous LDH }} \times 100 \%$

A total superoxide dismutase (T-SOD) assay kit (Nanjing Jiancheng Bioengineering Institute, China) and a catalase (CAT) assay kit (Nanjing Jiancheng Bioengineering Institute, China) were used to measure the intracellular SOD and CAT activities, respectively. The measuring methods and equations were the same as those used for LDH in accordance with the manual.

\section{Examination of the Cell Membranes by Transmission Electron Microscopy (TEM)}

Cell cultures $\left(10^{8} \mathrm{CFU} / \mathrm{ml} ; 1 \mathrm{ml}\right)$ were mixed with $99 \mathrm{ml}$ of aqueous ozone at a concentration of $1.0 \mathrm{mg} / 1$ for $1 \mathrm{~min}$. In the control sample, stroke-physiological saline solution was used instead of aqueous ozone. Cells were first fixed with $2.5 \%$ glutaraldehyde solution in phosphate buffer $(\mathrm{pH}$ 7.0) for more than $4 \mathrm{~h}$, and then washed with phosphate buffer three times. The samples were subsequently fixed with $1 \% \mathrm{OsO}_{4}$ in phosphate buffer ( $\mathrm{pH}$ 7.0) for 1-2 $\mathrm{h}$ and then washed three times in the phosphate buffer. The cells were then dehydrated with a graded ethanol series $(50 \%, 70 \%, 80 \%, 90 \%$, and $95 \%)$ for approximately 15-20 min at each step, and transferred into a mixture of ethanol and isoamyl acetate $(1: 1(\mathrm{v} / \mathrm{v}))$ for $30 \mathrm{~min}$, followed by the purification of the isoamyl acetate for 1-2 h. Furthermore, cells were dehydrated in a Hitachi Model HCP-2 critical point dryer with liquid $\mathrm{CO}_{2}$. At the final step, the dehydrated samples were coated with gold-palladium and observed by TEM (300 kV TEM H-9500; Hitachi, Japan).

Detection of the Integrity of Genetic Material by Electrophoresis

As with the method for measuring the zeta potential, the same number of cell pellets were exposed to different concentrations of aqueous ozone. The samples were then centrifuged and their genomic DNA was extracted using a MiniBEST Bacterial Genomic DNA Extraction Kit (TaKaRa, China), and the total RNA was extracted by TRIzol reagent (Invitrogen, USA). The nucleotide concentrations were quantified using a NanoDrop 2000 spectrophotometer (Thermo Fisher Scientific, USA). The integrity of the nuclei acid was verified using $1 \%(\mathrm{w} / \mathrm{v})$ agarose gel electrophoresis by loading the same volume of gDNA or total RNA.

\section{Transcriptome Sequencing and Analysis}

The cell cultures $\left(10^{8} \mathrm{CFU} / \mathrm{ml} ; 10 \mathrm{ml}\right)$ were mixed with $990 \mathrm{ml}$ of aqueous ozone at concentrations of 0.1 and $1.0 \mathrm{mg} / 1$ for $1 \mathrm{~min}$. When the reactions were terminated, the cells were subsequently spun down at $3,000 \mathrm{~g}$ for $1 \mathrm{~min}$ by a swing rotor centrifuge (Eppendorf, Germany). The above steps of termination and centrifuge lasted less than $5 \mathrm{~min}$. The TRIzol reagent was immediately added to the centrifuge tube to inhibit RNase activity. The cells were homogenized with TRIzol reagent and then with chloroform. Finally, total RNA was precipitated in the aqueous layer with isopropanol by centrifuging and submitted to Zhejiang Tianke Co., Ltd. (Hangzhou, China). Contaminating DNA in the RNA samples was removed by TURBO DNase (Ambion), and then the ribosomal RNA was removed using a MICROBExpress Bacterial mRNA Enrichment Kit (Ambion, USA) according to the manual. The integrity and concentration of the purified and enriched mRNA were assessed by an Agilent 2100 Bioanalyzer (Agilent Technologies, USA). The rRNA-depleted samples were subsequently fragmented and then synthesized into cDNA using SuperScript III Rev Transcriptase (Invitrogen, USA) combined with random primers (Invitrogen, USA). Paired-end library construction was performed using $2 \mu \mathrm{g}$ of total RNA, and its quality was verified again by the Bioanalyzer. RNA-Seq was performed on the Illumina HiSeq 2000 platform [28].

Adapters and poor quality base pairs were filtered out by Trimmomatic software [29], and repeated reads were removed by FastUniq software [30]. Those clean reads were then mapped to 
the $V$. parahaemolyticus reference genome (ftp://ftp.ncbi.nih.gov/ genomes/Bacteria/Vibrio_parahaemolyticus_RIMD_2210633_uid57969) using TopHat 2.0.11, and differential expression analysis was performed using Cuffdiff 2.0.2 according to the fragments per kilobase of the exon model per million mapped reads [31, 32]. The criterion for a significant up-regulation or down-regulation was a $p$-value $<0.05$.

\section{Quantitative PCR}

The total RNA extraction, the removal of DNA contamination, and the cDNA synthesis were performed as described for the transcriptome sequencing. A Power SYBR Green Master Mix (Applied Biosystems, USA) was used for quantitative PCR (qPCR), which was conducted using a QuantStudio 6 Flex RealTime PCR System (Applied Biosystems, USA). The 16S rRNA gene was selected as an endogenous control [33], and the target gene IDs and primer sequences are listed in Table S2. The qPCRs and the calculation of the relative expression levels of genes were performed as previously described [34, 35].
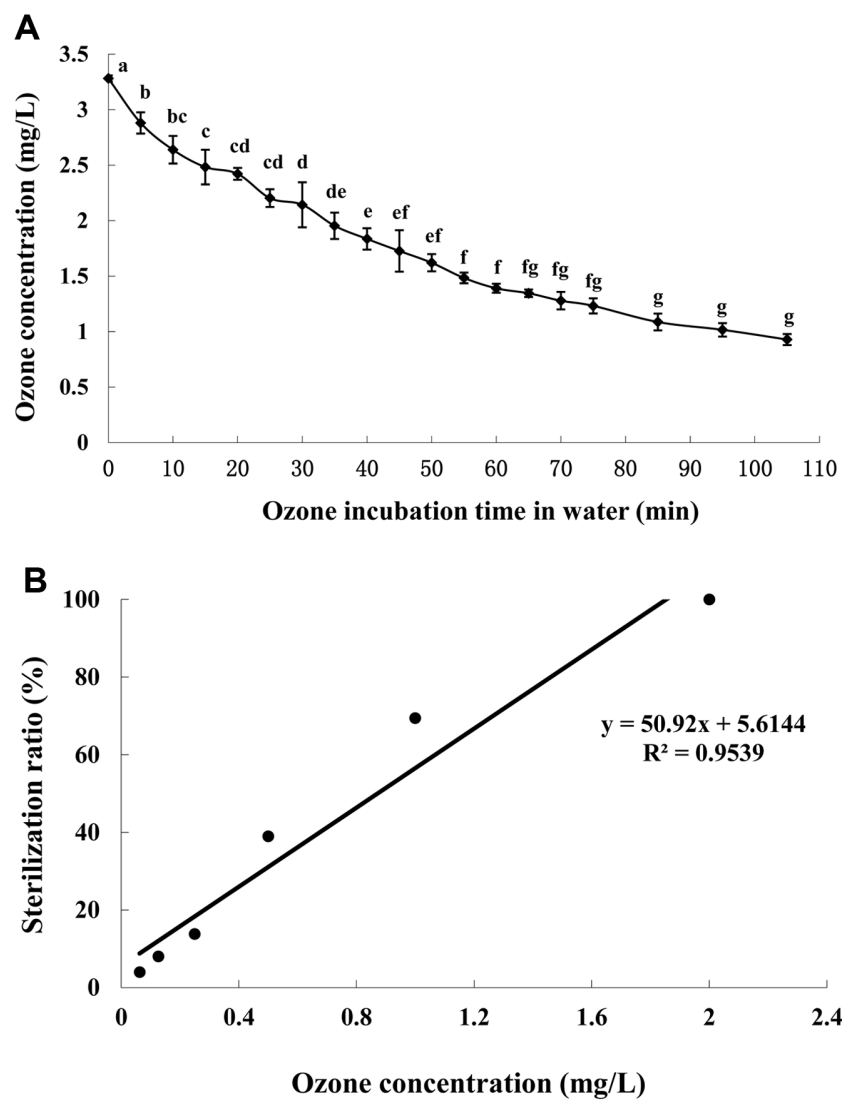

\section{Statistics}

All the analyses were performed in triplicate. Mean values were reported with standard deviations for each case. One-way analysis of variance (ANOVA) was performed for all data, and mean separations were conducted by Tukey's multiple range test (SPSS 13.0). Differences were considered significant at $p$-values $<0.05$.

\section{Omics Data}

All Illumina RNA sequencing data were submitted to the NCBI Short Read Archive (http://www.ncbi.nlm.nih.gov/sra), and their accession numbers are SRR6488512-SRR6488514.

\section{Results and Discussion}

\section{Ozone Degradation Tendency in Water}

Ozone is much more stable as a gaseous phase than an aqueous phase. Gaseous ozone has been used to sterilize and disinfect air and household disinfection cabinets, whereas aqueous ozone was used to sterilize drinking water,
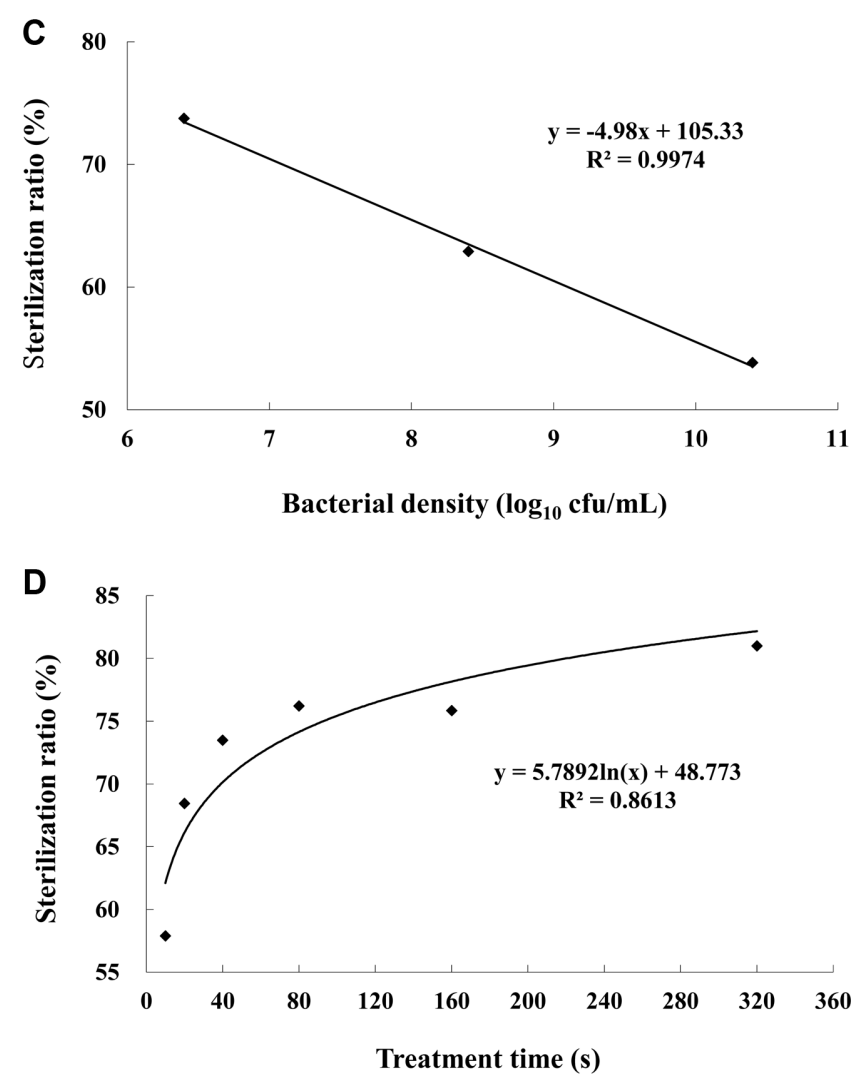

Fig. 1. Aqueous ozone degradation and its sterilization effects on Vibrio parahaemolyticus.

(A) Tendency of aqueous ozone to degrade in water at room temperature. Significant change $(p \leq 0.05)$ of the aqueous ozone concentration is indicated by lowercase letters. (B) Sterilization ratio under different aqueous ozone concentrations while the bacterial density and exposure time were fixed. (C) Sterilization ratio under different bacterial densities while the aqueous ozone concentration and exposure time were fixed. (D) Sterilization ratio under different exposure times while the aqueous ozone concentration and bacterial density were fixed. 
Table 1. Ranges and levels of variables in the Box-Behnken statistical experimental design.

\begin{tabular}{lcccc}
\hline \multirow{2}{*}{ Independent variables } & \multirow{2}{*}{ Symbol } & \multicolumn{3}{c}{ Coded variable level } \\
\cline { 3 - 5 } & & Minimum & Medium & Maximum \\
\hline Aqueous ozone concentration $(\mathrm{mg} / \mathrm{l})$ & $A$ & 0.063 & 0.631 & 1.2 \\
Bacterial density $\left(\log _{10} \mathrm{CFU} / \mathrm{ml}\right)$ & $B$ & 4 & 6 & 8 \\
Time exposed to aqueous ozone $(\mathrm{sec})$ & $C$ & 10 & 165 & 320 \\
\hline
\end{tabular}

wastewater, fruits, and juice $[6,9,10]$. V. parahaemolyticus is widely present in shallow seawater and attached to the body surfaces of marine food product. Therefore, aqueous ozone was selected to sterilize $V$. parahaemolyticus. However, the stability of aqueous ozone is affected by its concentration, temperature, $\mathrm{pH}$, presence of organic matter and metal ions, and UV exposure [36]. In order to determine the ozone degradation tendency in water, the aqueous ozone concentration was detected by iodometry when produced. The aqueous ozone $(3.3 \mathrm{mg} / \mathrm{l})$ started to break down dramatically in the first $20 \mathrm{~min}$ at room temperature, and it remained stable for 45-75 min; moreover, the change in absolute value of aqueous ozone concentration was relatively smooth from 60 to $75 \mathrm{~min}$ (Fig. 1A). Therefore, aqueous ozone was chosen as the experimental material at $60 \mathrm{~min}$.

\section{Sterilization Effect of Aqueous Ozone on V. parahaemolyticus}

Initial preliminary experiments were conducted following the single-factor experimental method to determine the most influential parameters that affected the bacterial sterilization ratio. Three parameters, the aqueous ozone concentration, aqueous ozone exposure time, and bacterial density, exerted dominant effects during E. coli inactivation [16], and they were selected as single factors in this study. The three experimental parameters were optimized on basis of the sterilization ratio obtained from the singlefactor study. Fig. 1B shows the effects of different concentrations of aqueous ozone on $V$.parahaemolyticus when the bacterial density and the exposure time were fixed. The sterilization was gradually enhanced with the increasing aqueous ozone concentration, and the relationship was linear. However, when both the concentration and the aqueous ozone exposure time were fixed, the sterilization efficacy declined with the increasing bacterial density (Fig. 1C). With fixed concentrations of aqueous ozone and bacterial density, the sterilization effect was enhanced when the exposure time was increased (Fig. 1D). The sterilization trends of aqueous ozone on $V$. parahaemolyticus were consistent with those reported in E. coli $[15,16]$, and thus the next step was to determine the dominant factor in the sterilization effect.

\section{Key Factor Analysis for the Sterilization Ratio of Aqueous Ozone}

The above three selected experimental parameters were optimized using response surface methodology by considering them as independent variables. A BoxBehnken design was adopted to evaluate the combined effect of the three independent variables using 17 sets of experiments. Both the ranges and levels of independent variables as well as details of designed experiments are shown in Tables 1 and 2, respectively.

Combined with the results of Tables 1 and 2, the formation of second-order quadratic polynomial models

Table 2. Box-Behnken experiments.

\begin{tabular}{|c|c|c|c|c|}
\hline $\begin{array}{c}\text { Serial } \\
\text { No. }\end{array}$ & $\begin{array}{l}\text { Aqueous ozone } \\
\text { concentration } \\
(\mathrm{mg} / \mathrm{l})\end{array}$ & $\begin{array}{c}\text { Bacterial } \\
\text { density } \\
\left(\log _{10} \mathrm{CFU} / \mathrm{ml}\right)\end{array}$ & $\begin{array}{l}\text { Aqueous } \\
\text { ozone } \\
\text { treatment } \\
\text { time (sec) }\end{array}$ & $\begin{array}{l}\text { Sterilization } \\
\text { ratio }(\%)\end{array}$ \\
\hline 1 & 0.06 & 4 & 165 & 10.48 \\
\hline 2 & 1.20 & 4 & 165 & 100.00 \\
\hline 3 & 0.06 & 8 & 165 & 4.76 \\
\hline 4 & 1.20 & 8 & 165 & 100.00 \\
\hline 5 & 0.06 & 6 & 10 & 5.91 \\
\hline 6 & 1.20 & 6 & 10 & 100.00 \\
\hline 7 & 0.06 & 6 & 320 & 7.64 \\
\hline 8 & 1.20 & 6 & 320 & 100.00 \\
\hline 9 & 0.63 & 4 & 10 & 26.81 \\
\hline 10 & 0.63 & 8 & 10 & 26.00 \\
\hline 11 & 0.63 & 4 & 320 & 53.32 \\
\hline 12 & 0.63 & 8 & 320 & 45.14 \\
\hline 13 & 0.63 & 6 & 165 & 25.54 \\
\hline 14 & 0.63 & 6 & 165 & 35.16 \\
\hline 15 & 0.63 & 6 & 165 & 27.31 \\
\hline 16 & 0.63 & 6 & 165 & 33.36 \\
\hline 17 & 0.63 & 6 & 165 & 30.48 \\
\hline
\end{tabular}


Table 3. ANOVA results of the response surface quadratic model for the sterilization ratio.

\begin{tabular}{lrcrrr}
\hline $\begin{array}{l}\text { Source of } \\
\text { variance }\end{array}$ & $\begin{array}{c}\text { Sum of } \\
\text { squares }\end{array}$ & $\begin{array}{c}\text { Degrees of } \\
\text { freedom }\end{array}$ & $\begin{array}{c}\text { Mean } \\
\text { square }\end{array}$ & $F$-value & $p$ Value \\
\hline Model & $19,358.26$ & 9 & $2,419.78$ & 62.81 & $<0.0001$ \\
$A$ & $17,224.57$ & 1 & $17,224.57$ & 447.12 & $<0.0001$ \\
$B$ & 27.07 & 1 & 27.07 & 0.70 & 0.4262 \\
$C$ & 280.61 & 1 & 280.61 & 7.28 & 0.0271 \\
$A B$ & 8.19 & 1 & 8.19 & 0.21 & 0.6571 \\
$B C$ & 13.56 & 1 & 13.56 & 0.35 & 0.5694 \\
$A C$ & 10.43 & 1 & 10.41 & 0.28 & 0.5945 \\
$A^{2}$ & $1,601.91$ & 1 & $1,601.91$ & 41.58 & 0.0002 \\
$B^{2}$ & 65.33 & 1 & 65.33 & 1.70 & 0.2291 \\
$C^{2}$ & 51.99 & 1 & 51.99 & 1.35 & 0.2789 \\
Residual & 308.18 & 7 & 38.52 & & \\
Lack of fit & 243.59 & 3 & 60.90 & 3.77 & 0.1134 \\
Pure error & 64.60 & 4 & 16.15 & & \\
Total & $19,666.44$ & 16 & & & \\
& $R^{2}=$ & Adj $R^{2}=$ & & & \\
\hline & 0.9843 & 0.9687 & & & \\
\hline
\end{tabular}

was developed using Design-Expert 7.0.0 software to establish the sterilization ratio of $V$. parahaemolyticus when treated with aqueous ozone as follows:

Sterilization ratio $(\%)=40.4247-2.0881 \times A-12.5508 \times B$ $+0.0256 \times C+1.2576 \times A B-0.0059 \times B C+0.153 \times A C+$ $60.2987 \times A^{2}+0.9848 \times B^{2}+0.0001 \times C^{2}$

The experimental data for the sterilization ratio were statistically analyzed by variance (Table 3 ). The F-value of the model was 62.81 , and the corresponding $p$-value was $<0.0001$, which indicated the model was highly significant. The lack of $F$-value fit at 3.77 was not significant, because the corresponding $p$-value was $>0.05$. An insignificant $p$-value can be used to predicate the lack of fit [26]. The predicted $R^{2}$ value of 0.9843 was consistent with the corresponding adjusted $R^{2}$ value of 0.9687 . In a model, better $R^{2}$ values should be close to 1 to fit the experimental data [26]. The independent variables of the quadratic polynomial models $A$ and $C$, and the quadratic term $A^{2}$ were highly significant because the $p$-value for them was $<0.05$, whereas the remaining model, interaction, or quadratic terms had high $p$-values of more than 0.05 . Therefore, model $A$ of the aqueous ozone concentrations was found to be the most influential factor in the sterilization ratio, but all the other factors were also important.

\section{The Cell Membrane Was Damaged by Aqueous Ozone Treatment}

Regarding unicellular organisms, the interfacial surface physiology that is regarded as maintaining optimal cell function is particularly important. Ionized substituents and phosphoryl groups on the outer cell envelopes cause bacterial surfaces to possess a net negative electrostatic charge. Thus, the degree of peripheral electronegativity of a cell surface can be assessed by using the zeta potential $[27,37]$. Lower zeta potentials could be observed in dead bacterial cells [38]. In this study, the zeta potential would stabilize if the aqueous ozone concentration was lower than $0.2 \mathrm{mg} / \mathrm{l}$. When the concentration was higher than $0.4 \mathrm{mg} / \mathrm{l}$, the zeta potential decreased gradually with the increasing aqueous ozone concentration. When the concentration was $1.2 \mathrm{mg} / \mathrm{l}$, the zeta potential was reduced by $30.5 \%$ compared with the control sample (Fig. $2 \mathrm{~A}$ ). The result suggested that aqueous ozone influenced the overall polarity of the bacterial surface that might underlie the integrity of the cell membrane.

LDH is present in almost all living cells (animals, plants, and prokaryotes), catalyzing the conversion of lactate to pyruvate and back to lactate. As a soluble cytoplasmic enzyme, it is released into the extracellular space when the plasma membrane is damaged [39]. With the increasing aqueous ozone concentration, the amount of enzyme was also increased (Fig. 2B), showing a dose-response relationship, and suggesting the cell envelope was damaged during ozonation.

Furthermore, the ultrastructure of the cell was observed by TEM to determine the morphological changes in the internal and external cell structures after applying aqueous ozone. After aqueous ozone treatment, the irregular shape and rupture of the cell wall were observed, and the majority of the cells appeared to be hollow, which may have been caused by the loss of cell contents (Fig. 2C), such as LDH. Control cells without aqueous ozone treatments had intact cell walls and membranes, and a uniform cell cytoplasm (Fig. 2D). The effect was similar to that observed in E. coli in which the surface structure was damaged after ozonation as shown by both TEM and scanning electron microscope analyses $[17,40]$. Therefore, the cell membrane integrity can be damaged by aqueous ozone, which results in loss of the cellular contents (e.g., enzyme, genetic materials) and finally leads to cell death.

\section{Intracellular Antioxidant Enzymes Detoxified a Certain Concentration of Aqueous Ozone}

Reactive oxygen species can induce damage in the 


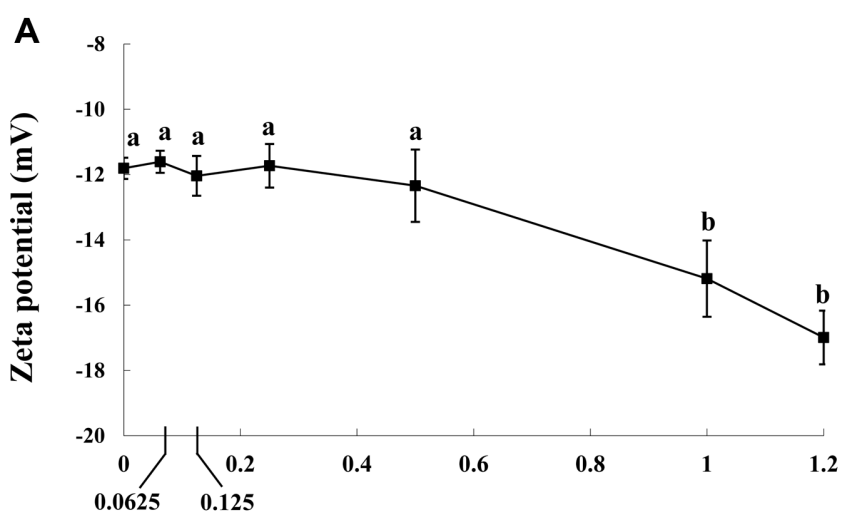

Ozone concentration (mg/L)

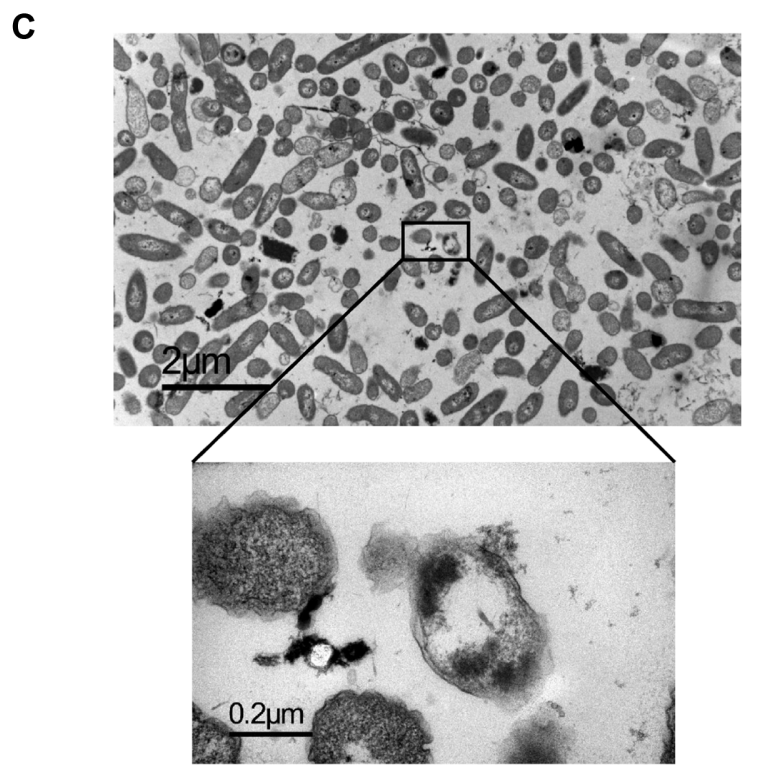

B

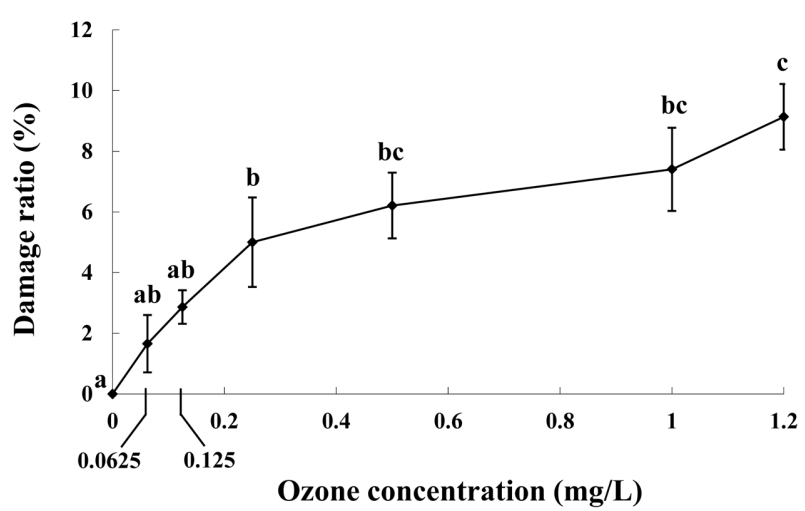

D

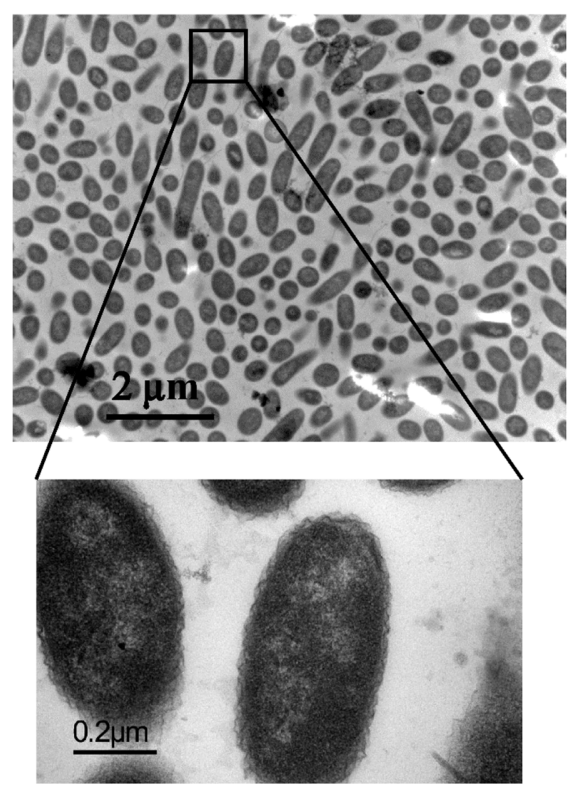

Fig. 2. Cell membrane damage after aqueous ozone treatment.

(A) The degree of peripheral electronegativity on the cell surface was assessed by using the zeta potential. (B) Cell membrane permeability was assessed by observing the lactate dehydrogenase content. Significant change $(p \leq 0.05)$ of the aqueous ozone concentration is indicated by lowercase letters. (C) TEM examination of cells under aqueous ozone treatment of $1 \mathrm{mg} / 1$ for $1 \mathrm{~min}$. (D) TEM examination of cells without aqueous ozone treatment.

genetic material and then lead to genetic lesions (e.g., mutagenic activity and tumorigenicity). Both superoxide dismutase and catalase are the most important and common enzymes involved in the decomposition of reactive oxygen species, and their levels are related to the concentration of reactive oxygen species within the cell [41]. The SOD activity showed a progressive increase after the cells were treated with low concentrations of aqueous ozone (0$0.125 \mathrm{mg} / \mathrm{l})$. When the concentration of aqueous ozone was $0.125 \mathrm{mg} / \mathrm{l}$, the SOD activity was $89.61 \pm 4.85 \mathrm{U} / \mathrm{mg}$ protein, which was $116 \%$ of the control sample (Fig. 3A). This finding illustrated that a low concentration of aqueous ozone might diffuse into the cell and then stimulate the activity of the SOD antioxidant. However, as the aqueous ozone concentration increased, the SOD activity decreased. The activity was $39.68 \pm 4.32 \mathrm{U} / \mathrm{mg}$ protein when treated with $1.2 \mathrm{mg} / \mathrm{l}$ aqueous ozone, which was $52 \%$ of the control sample. A high concentration of aqueous ozone exceeded the antioxidant capacity of the intracellular SOD, which broke the antioxidant balance. The effects on CAT were similar to those of SOD when treating with aqueous ozone (Fig. 3B). The CAT activity also showed a progressive 
A

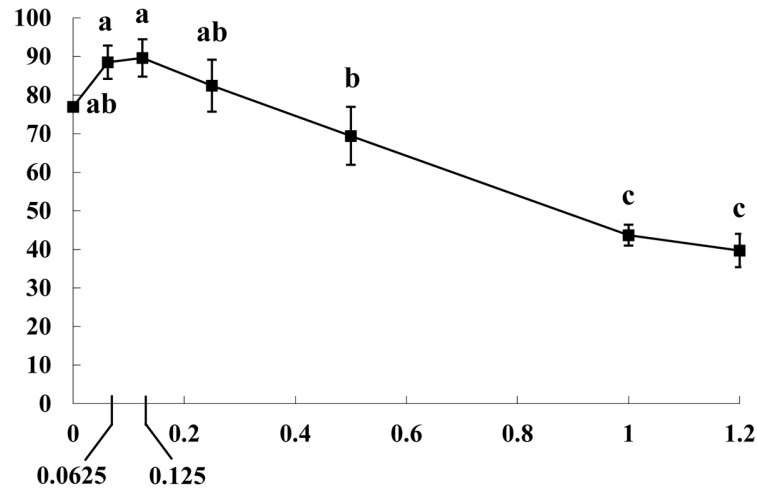

Ozone concentration $(\mathrm{mg} / \mathrm{L})$

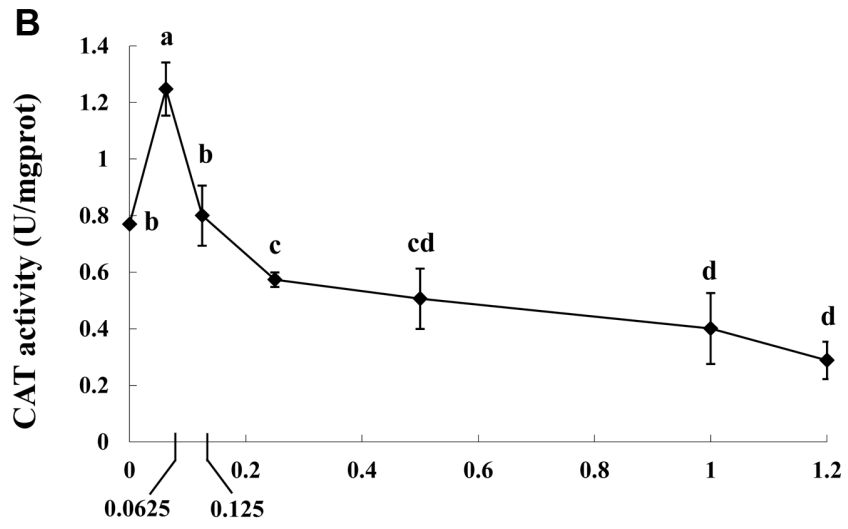

Ozone concentration $(\mathrm{mg} / \mathrm{L})$

Fig. 3. Intracellular antioxidant enzyme activity of cells after aqueous ozone treatment of $0-1.2 \mathrm{mg} / 1$ for $1 \mathrm{~min}$.

(A) SOD activity. (B) CAT activity. Significant change $(p \leq 0.05)$ of the aqueous ozone concentration is indicated by lowercase letters.

increase with low concentrations of aqueous ozone (0$0.0625 \mathrm{mg} / \mathrm{l})$. The activity of CAT was $0.29 \pm 0.07 \mathrm{U} / \mathrm{mg}$ protein when treated with $1.2 \mathrm{mg} / \mathrm{l}$ aqueous ozone, which was $37.47 \%$ of the control sample. This phenomenon conformed to the characteristics of the hormesis, a doseresponse relationship characterizing a biphasic dose response to stressors with favorable response to a low dose but detrimental effect at a higher dose. Almost all of the organisms have this characteristic. The hormetic response, a low-dose ozone or oxidative preconditioning promoting the synthesis of enzymes (e.g., SOD, CAT, GPx, and GR) to defend oxidants, has been demonstrated in experimental animals and patients [42]. In this study, both SOD and CAT in $V$. parahaemolyticus conferred protection to the cells at a certain low concentration but lost activity at high concentrations of aqueous ozone treatment, suggesting

\section{Aqueous ozonetreatment(mg/L)}

A

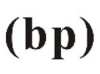

23130

9416

6557

4361

2322

2027

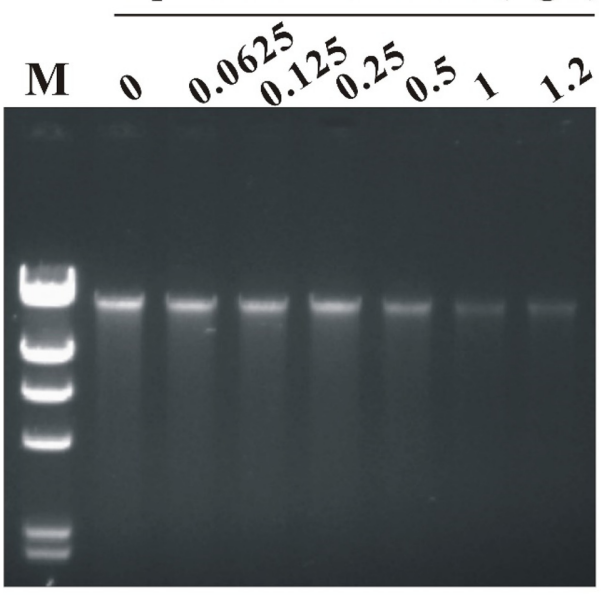

\section{Aqueous ozone treatment(mg/L)}

B

(bp)

2000

1500

1000

700

400

200

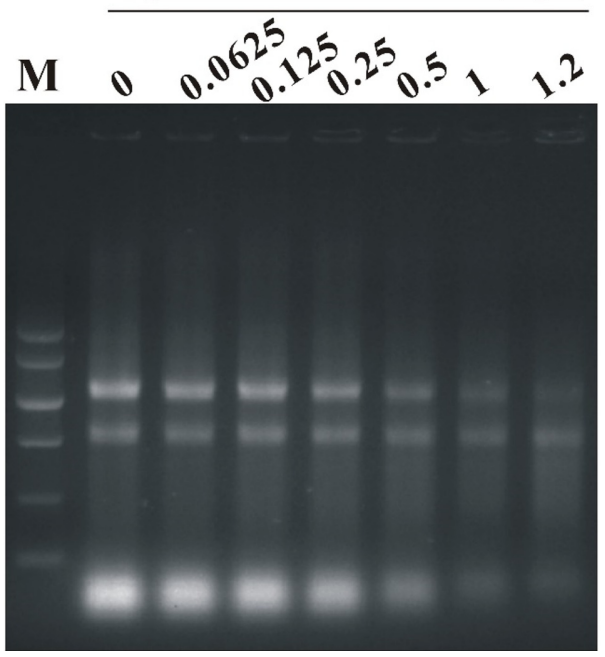

Fig. 4. Genetic materials in the cells after aqueous ozone treatment of $0-1.2 \mathrm{mg} / 1$ for $1 \mathrm{~min}$.

(A) Degradation of gDNA. (B) Degradation of total RNA.

hormesis existed in V. parahaemolyticus, and aqueous ozone was its stressor.

\section{Aqueous Ozone Degraded Genetic Materials}

The genetic materials DNA and RNA are repositories of information in every living cell, and thus their integrity and stability are crucial to life [43]. Previous studies showed that ozone treatment led to E. coli DNA lesions with mutations, in which the massive breakdown of DNA would be lethal if not repaired by DNA polymerase [20]. Therefore, some investigators introduced ozone to degrade antibiotic resistance genes that were escaping to the environment after cell membranes were damaged in E. coli 
and other bacteria from wastewater $[19,44]$. In this study, both genomic DNA and total RNA were visualized by ethidium bromide staining after $V$. parahaemolyticus cells were treated with a series of aqueous ozone concentrations (Figs. 4A and 4B). A low concentration of aqueous ozone (less than $0.25 \mathrm{mg} / \mathrm{l}$ ) had little effect on the integrity of the genomic DNA and total RNA. When the concentration was approximately $0.5 \mathrm{mg} / \mathrm{l}$, the bands of genomic DNA and total RNA began to fade. If the concentration was greater than $1 \mathrm{mg} / \mathrm{l}$, the sterilization ratio was more than $56.53 \%$ (Fig. 1B), and the damage to the genomic DNA and total RNA very obviously resulted in faint bands, suggesting the massive breakdown of both DNA and RNA was lethal for cells. Moreover, the read numbers from the transcriptome sequencing showed that the high-concentration treatment of $1 \mathrm{mg} / 1(3,737,032)$ produced much fewer numbers than either the control $(5,695,016)$ or the low concentration of $0.1 \mathrm{mg} / 1(5,632,096)$ (Table S3), indicating the gene expression profile only corresponded to surviving bacteria. Therefore, the genetic materials of $V$. parahaemolyticus were barely damaged by a low concentration $(\leq 0.1 \mathrm{mg} / \mathrm{l})$, whereas they were severely degraded at high concentrations $(\geq 1 \mathrm{mg} / \mathrm{l})$. This phenomenon might be one of the most important reasons to respond to the linear relationship between the sterilization ratio and the aqueous ozone concentration (Fig. 1B).

\section{Transcriptome Sequencing of Whole-Genome Expression} Profiling for Cells under Aqueous Ozone Stress

To obtain a deep understanding of the molecular mechanisms of $V$. parahaemolyticus in response to aqueous ozone stress, large-scale transcriptome sequencing of cells was performed under aqueous ozone stress using the Illumina sequencing technology. After removing the adaptor and the low-quality and repeated sequences, as well as possible viruses, the reads were obtained and could be mapped to the $V$. parahaemolyticus reference genome (RIMD_2210633) (Table S3), and then they were assembled de novo to generate 8,440 unique transcripts (Fig. S1). A total of 4,832 genes mapped exactly to all the genes within the $V$. parahaemolyticus RIMD_2210633 strain [32]. To validate the RNA-Seq expression profile data, 21 genes were selected randomly for qPCR confirmation (Tables S2 and S4). A high correlation was observed between the two methods $\left(R^{2}=0.9299\right)$ identified by a simple linear regression equation as follows: $y=1.1944 x-0.1005$ (Fig. 5A).

The above results (Figs. 2-4) showed that high concentrations of aqueous ozone significantly affect the phenotype of cells (e.g., cell membrane, enzyme, and genetic materials). A genome-level screening using RNASeq would be more suitable for uncovering the molecular mechanism of aqueous ozone sterilization. There were 75 and 47 genes that were up- or down-regulated by more than 2-fold in response to exposure to 0.1 and $1 \mathrm{mg} / \mathrm{l}$ aqueous ozone, respectively $(P<0.05)$ (Table S5). The overlapping genes (VPA0061, VPA0084, VPA0171, VPA1017, VP2010, VP2421, and VP2422) were summarized in a Venn diagram (Fig. 5B), and their relative expression levels under different concentrations of aqueous ozone treatment were provided (Fig. 5C).
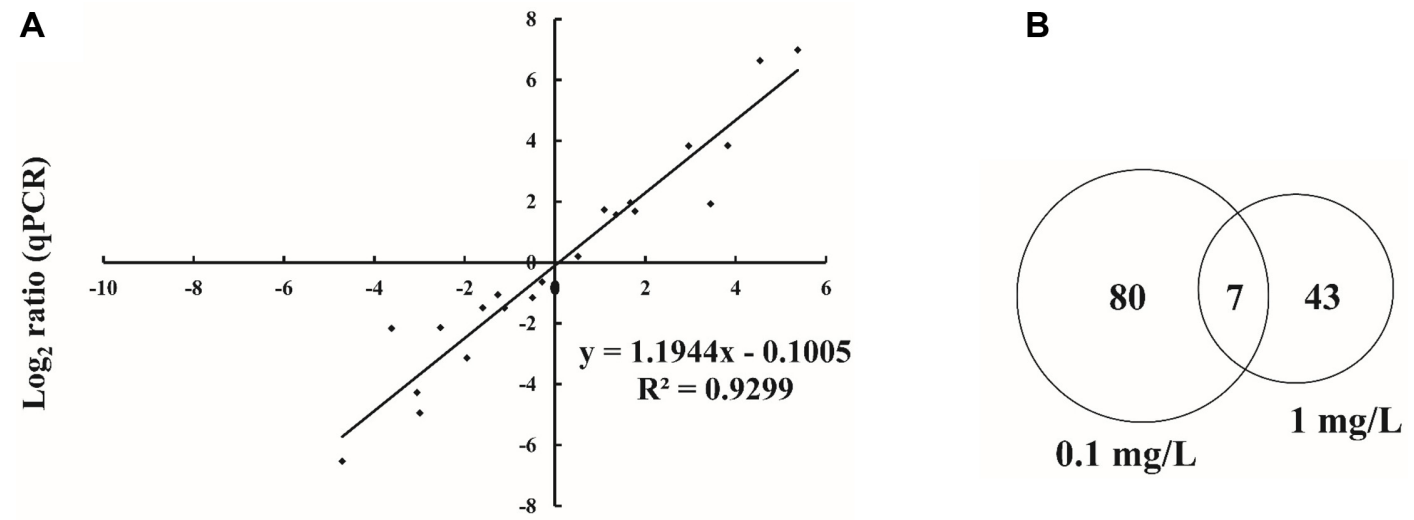

$\log _{2}$ ratio (RNA-seq)

Fig. 5. Gene expression profiling of cells after aqueous ozone treatment.

(A) Gene expression levels with a correlation between RNA-Seq ( $x$-axis) and qPCR ( $y$-axis). Each $\log _{2}$ ratio of fold changes was compared between RNA-Seq and qPCR. (B) A Venn diagram of up- or down-regulated genes after exposure to aqueous ozone treatments. (C) Gene expression levels determined by qPCR. Error bars represent the standard deviation. 

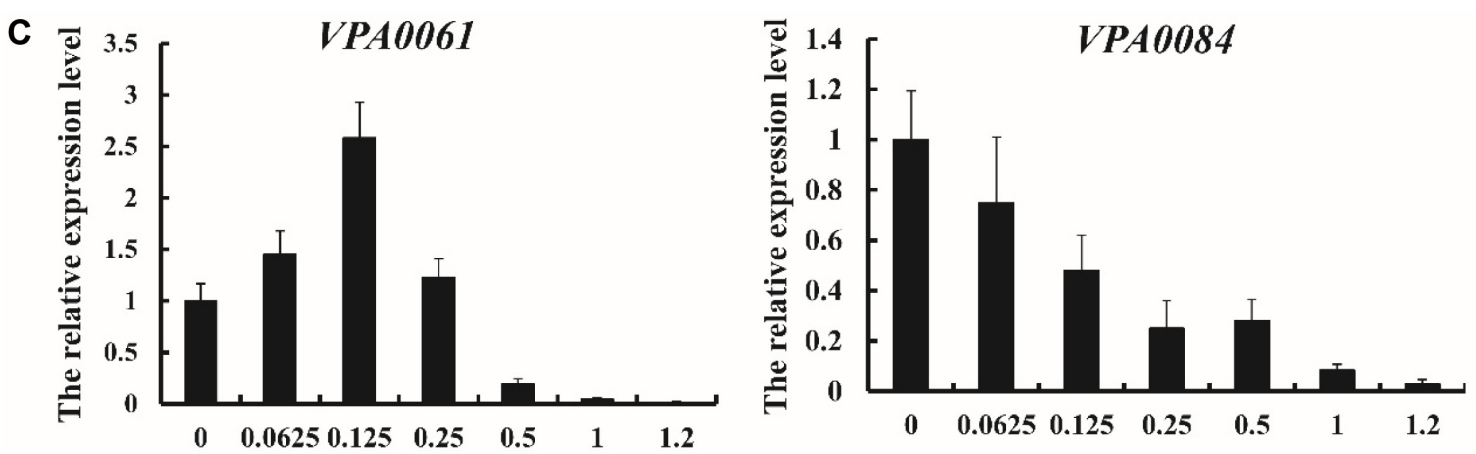

Ozone concentration $(\mathrm{mg} / \mathrm{L})$
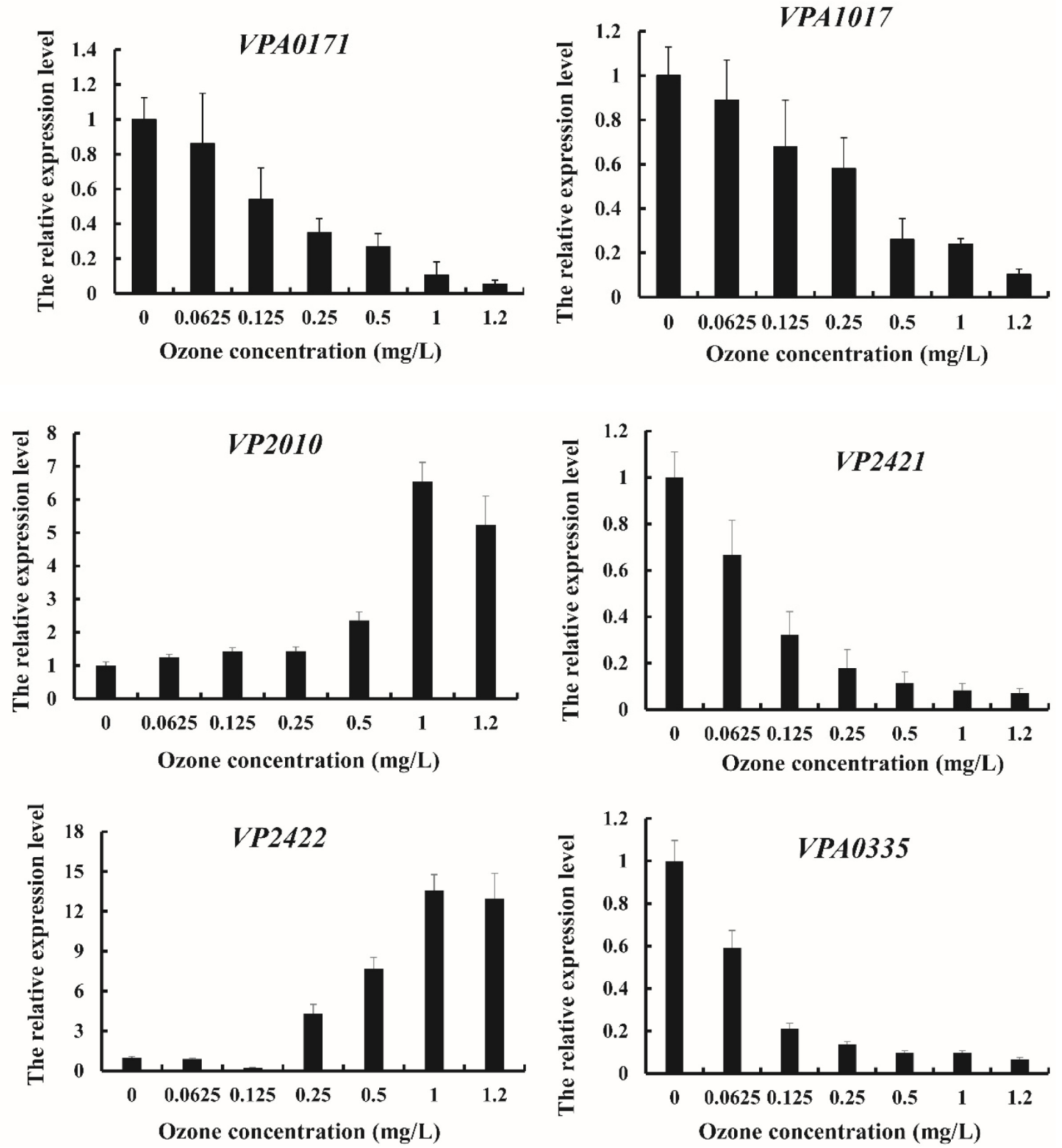

Fig. 5. Continued. 
A

$\%$ Seqs

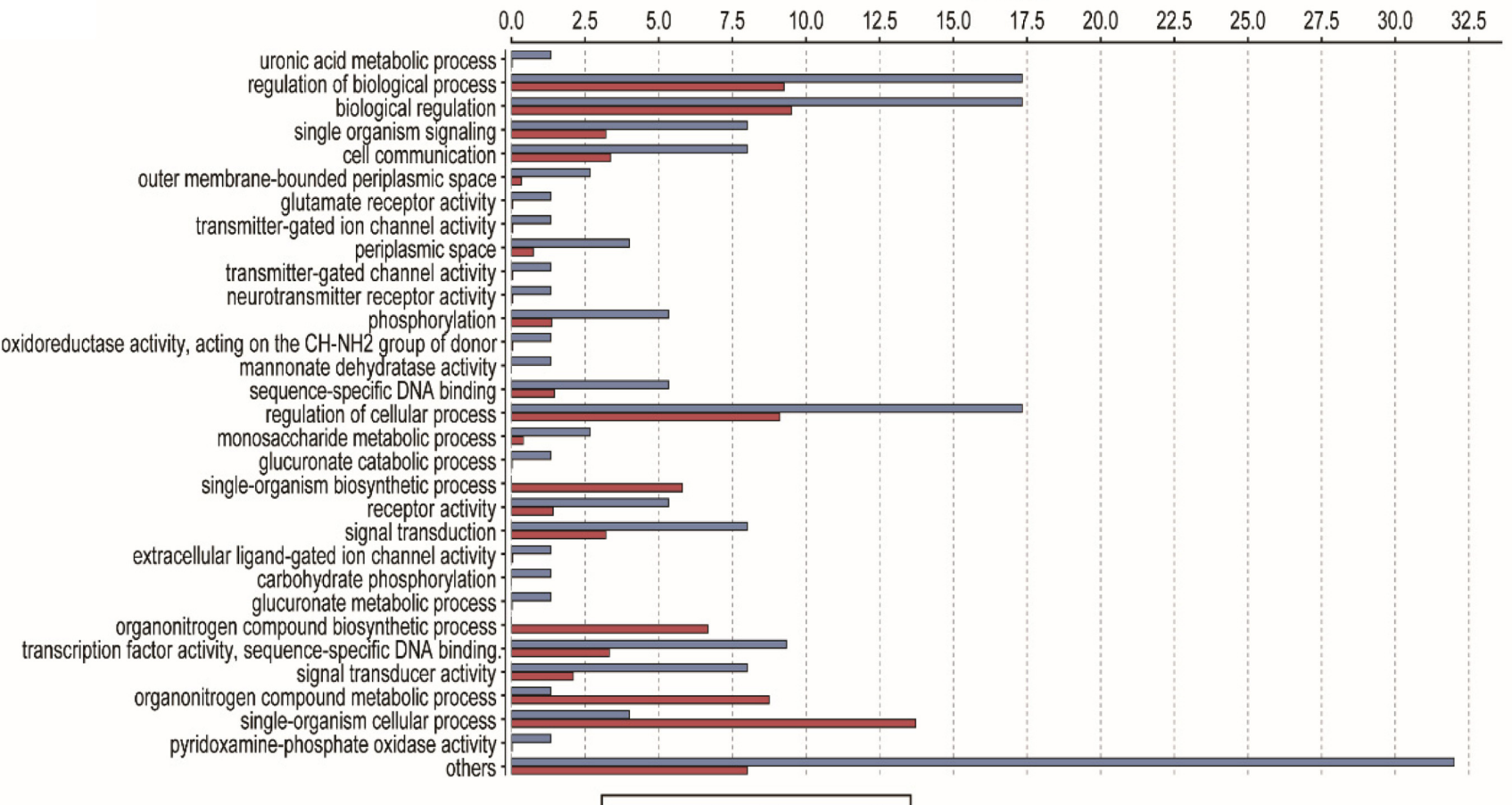

$\square$ Test Set $\square$ Reference Set

B

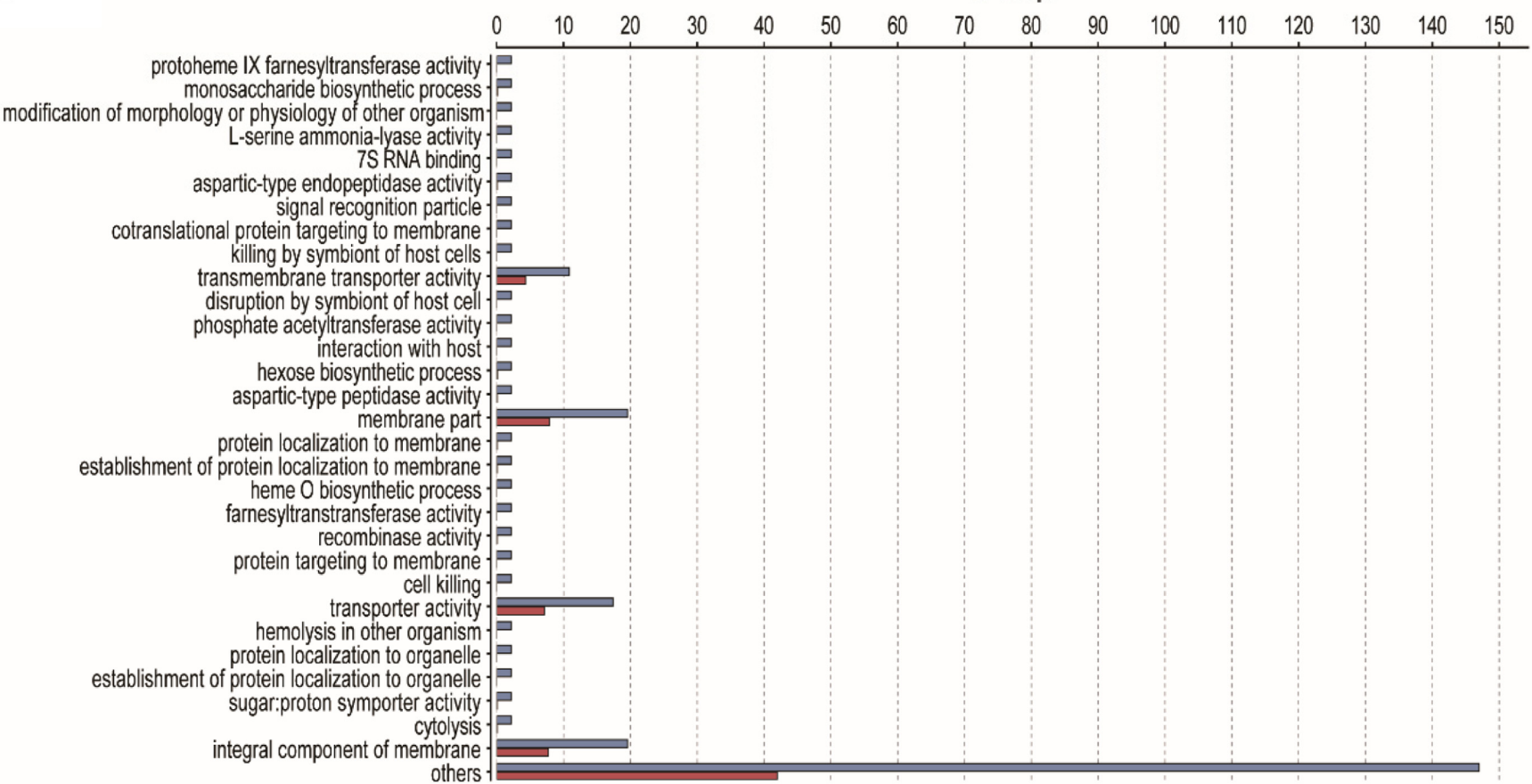

Test Set $\square$ Reference Set

Fig. 6. Gene Ontology enrichment grouping in V. parahaemolyticus under aqueous ozone treatment.

(A) Aqueous ozone $0.1 \mathrm{mg} / 1$ treatment; and (B) $1.0 \mathrm{mg} / 1$ treatment. 
The VPA0061 gene is annotated as a MATE family efflux transporter that is involved in exporting metabolites across the cell membrane and responding to multidrug resistance in many bacteria and eukaryotic cells [45]. Under lowconcentration aqueous ozone treatment, its expression level was much higher than that of the control, which suggested that it acted as a pump to transport the ozone out of the cell to reduce oxidant harm. When the aqueous ozone concentration was higher than $0.25 \mathrm{mg} / \mathrm{l}$, the expression level of the VPA0061 gene was inhibited, indicating that the DNA and RNA began to enter into an unstable status and could not complete their transcription progress. The VPA0084, VPA0171, VPA1017, and VP2421 genes are annotated as encoding a transporter, hydrolase, transcriptional regulator, and AAA family ATPase, respectively. Their expression levels were inhibited when cells were exposed to aqueous ozone. The VP2010 and VP2422 genes are annotated as encoding sensory histidine kinase and prepilin peptidase. With an increasing aqueous ozone concentration (0-1 mg/1), the expression levels of VP2010 and VP2422 were gradually increased; however, both of them were decreased at the highest concentration $(1.2 \mathrm{mg} / \mathrm{l})$. Therefore, the destruction of the genetic materials and the inhibition of gene expression are important methods for killing bacteria.

In E. coli, the oxidative stress-related genes soxRS and oxyR were confirmed to play an important role in protecting against ozone stress through DNA repair and the removal of radicals [17,46], and the regulon RpoS also conferred protection against radicals [17]. The VPA0335 gene, which was annotated as encoding a SoxR protein in $V$. parahaemolyticus, was screened out through transcriptome sequencing (Table S5) and was inhibited between the control and the aqueous ozone exposure concentrations (0.0625-1.2 $\mathrm{mg} / \mathrm{l}$ ) by qPCR (Fig. 5C). However, neither the soxS nor the rpoS gene was identified by transcriptome sequencing (Table S5). Under oxidative stress, SoxR induces the expression of SoxS that further promotes the SoxRS regulon in E. coli to confer protection against stress [46]. Thus, V. parahaemolyticus might have other regulon(s) to confer a certain increased degree of SOD and CAT activity at low concentrations of aqueous ozone (Figs. 3A and 3B) with the exception of SoxRS.

Enrichment analysis is a useful method for interpreting RNA-Seq data through the automatic functional categorization of gene lists [47]. Differently expressed genes at the 2-fold up- or down-regulation levels under each aqueous ozonetreated set were searched using the local Blast2go database [48]. The outputs include the three independent domains of biological processes, molecular function, and cellular components. Under low aqueous ozone concentration treatment, the majority of the most abundant genes were involved in many biological processes, including the regulation of biological processes, biological regulation, single organism signaling, cell communication, regulation of cellular processes, single transduction, signal transducer activity, and responding to stimuli (Fig. 6A). These findings indicated that $V$. parahaemolyticus received a stimulation from ozone and then transmitted the signal to the intracellular space, which induced the action of the membrane pump system to eliminate the ozone from the cell. The remnants of ozone were detoxified by intracellular antioxidant enzymes (e.g., SOD and CAT). Under high aqueous ozone concentrations, the expression levels of almost all genes were inhibited (Fig. 6B), indicating that the ozone molecules entered the cell from the damaged membrane, and then inhibited the enzymes and destroyed the genetic materials, which could represent a way of killing bacteria with high concentrations of aqueous ozone.

\section{Acknowledgments}

This work was supported by the National Natural Science Foundation of China (No. 31301566 and 31271954), Specialized Research Fund for the Doctoral Program of Higher Education (No. 20133326120008), and Food Science and Engineering-the Most Important Discipline of Zhejiang Province (No. JYTSP20142071).

\section{Conflict of Interest}

The authors have no financial conflicts of interest to declare.

\section{References}

1. Wang $\mathrm{W}, \mathrm{Li} \mathrm{M}, \mathrm{Li}$ Y. 2015. Intervention strategies for reducing Vibrio parahaemolyticus in seafood: a review. J. Food Sci. 80: R10-R19.

2. Letchumanan V, Chan KG, Lee LH. 2014. Vibrio parahaemolyticus: a review on the pathogenesis, prevalence, and advance molecular identification techniques. Front. Microbiol. 5: 705.

3. Su YC, Liu C. 2007. Vibrio parahaemolyticus: a concern of seafood safety. Food Microbiol. 24: 549-558.

4. Velazquez-Roman J, Leon-Sicairos N, de Jesus Hernandez-Diaz L, Canizalez-Roman A. 2013. Pandemic Vibrio parahaemolyticus O3:K6 on the American continent. Front. Cell. Infect. Microbiol. 3: 110. 
5. Elvis AM, Ekta JS. 2011. Ozone therapy: a clinical review. J. Nat. Sci. Biol. Med. 2: 66-70.

6. Guzel-Seydim ZB, Greene AK, Seydim AC. 2004. Use of ozone in the food industry. LWT Food Sci. Technol. 37: 453460.

7. Perry JJ, Yousef AE. 2011. Decontamination of raw foods using ozone-based sanitization techniques. Annu. Rev. Food Sci. Technol. 2: 281-298.

8. Glowacz M, Colgan R, Rees D. 2015. The use of ozone to extend the shelf-life and maintain quality of fresh produce. J. Sci. Food Agric. 95: 662-671.

9. Lee $Y$, Gerrity D, Lee M, Bogeat AE, Salhi E, Gamage S, et al. 2013. Prediction of micropollutant elimination during ozonation of municipal wastewater effluents: use of kinetic and water specific information. Environ. Sci. Technol. 47: 5872-5881.

10. von Gunten U. 2003. Ozonation of drinking water: part II. Disinfection and by-product formation in presence of bromide, iodide or chlorine. Water Res. 37: 1469-1487.

11. Song WJ, Shin JY, Ryu S, Kang DH. 2015. Inactivation of Escherichia coli O157:H7, Salmonella Typhimurium and Listeria monocytogenes in apple juice at different $\mathrm{pH}$ levels by gaseous ozone treatment. J. Appl. Microbiol. 119: 465-474.

12. Patil S, Valdramidis VP, Cullen PJ, Frias J, Bourke P. 2010. Inactivation of Escherichia coli by ozone treatment of apple juice at different pH levels. Food Microbiol. 27: 835-840.

13. Miller FA, Silva CLM, Brandão TRS. 2013. A review on ozone-based treatments for fruit and vegetables preservation. Food Eng. Rev. 5: 77-106.

14. Broadwater WT, Hoehn RC, King PH. 1973. Sensitivity of three selected bacterial species to ozone. Appl. Microbiol. 26: 391-393.

15. Patil S, Cullen PJ, Kelly B, Frias JM, Bourke P. 2009. Extrinsic control parameters for ozone inactivation of Escherichia coli using a bubble column. J. Appl. Microbiol. 107: 830-837.

16. Pavlovich MJ, Chang HW, Sakiyama Y, Clark DS, Graves DB. 2013. Ozone correlates with antibacterial effects from indirect air dielectric barrier discharge treatment of water. J. Phys. D Appl. Phys. 46: 145202.

17. Patil S, Valdramidis VP, Karatzas KA, Cullen PJ, Bourke P. 2011. Assessing the microbial oxidative stress mechanism of ozone treatment through the responses of Escherichia coli mutants. J. Appl. Microbiol. 111: 136-144.

18. Hess S, Gallert C. 2015. Sensitivity of antibiotic resistant and antibiotic susceptible Escherichia coli, Enterococcus and Staphylococcus strains against ozone. J. Water Health 13: 10201028.

19. Czekalski N, Imminger S, Salhi E, Veljkovic M, Kleffel K, Drissner D, et al. 2016. Inactivation of antibiotic resistant bacteria and resistance genes by ozone: from laboratory experiments to full-scale wastewater treatment. Environ. Sci. Technol. 50: 11862-11871.

20. Hamelin C, Sarhan F, Chung YS. 1977. Ozone-induced DNA degradation in different DNA polymerase I mutants of Escherichia coli K12. Biochem. Biophys. Res. Commun. 77: 220-224.

21. Feng LF, Cheng XB, He SS, Li JR. 2013. Identification and evaluation of Vibrio vulnificus-specific target genes. J. Fish. China 37: 790-800.

22. Zhang F, Zhu JL, Feng LF. 2016. Inhibition analysis of resveratrol against Vibrio parahaemolyticus biofilm based on RNA-Seq technology. Acta Microbiol. Sin. 56: 856-866.

23. The Chinese National Hygiene Ministry. 2010. Microbiological examination of food hygiene - examination of Vibrio parahaemolyticus. The National Standard of the People's Republic of China, GB 4789.2-2010. Beijing, China.

24. The Chinese National Hygiene Ministry. 2016. Food microbiological examination: aerobic plate count. The National Standard of the People's Republic of China, GB 4789.2-2016. Beijing, China.

25. Rakness K, Gordon G, Langlais B, Masschelein W, Matsumoto N, Richard Y, et al. 1996. Guideline for measurement of ozone concentration in the process gas from an ozone generator. Ozone Sci. Eng. 18: 209-229.

26. Sahoo C, Gupta AK. 2012. Optimization of photocatalytic degradation of methyl blue using silver ion doped titanium dioxide by combination of experimental design and response surface approach. J. Hazard. Mater. 215-216: 302-310.

27. Clogston JD, Patri AK. 2011. Zeta potential measurement. Methods Mol. Biol. 697: 63-70.

28. Kim S, Park J, Choi O, Kim J, Seo YS. 2014. Investigation of quorum sensing-dependent gene expression in Burkholderia gladioli BSR3 through RNA-Seq analyses. J. Microbiol. Biotechnol. 24: 1609-1621.

29. Bolger AM, Lohse M, Usadel B. 2014. Trimmomatic: a flexible trimmer for Illumina sequence data. Bioinformatics 30: 2114-2120.

30. Xu H, Luo X, Qian J, Pang X, Song J, Qian G, et al. 2012. FastUniq: a fast de novo duplicates removal tool for paired short reads. PLoS One 7: e52249.

31. Trapnell C, Roberts A, Goff L, Pertea G, Kim D, Kelley DR, et al. 2012. Differential gene and transcript expression analysis of RNA-Seq experiments with TopHat and Cufflinks. Nat. Protoc. 7: 562-578.

32. Makino K, Oshima K, Kurokawa K, Yokoyama K, Uda T, Tagomori K, et al. 2003. Genome sequence of Vibrio parahaemolyticus: a pathogenic mechanism distinct from that of $V$ cholerae. Lancet 361: 743-749.

33. Hoffmann M, Brown EW, Feng PCH, Keys CE, Fischer M, Monday SR. 2010. PCR-based method for targeting 16S-23S rRNA intergenic spacer regions among Vibrio species. BMC Microbiol. 10: 90.

34. Feng L, Fu C, Yuan D, Miao W. 2014. A P450 gene associated with robust resistance to DDT in ciliated protozoan, Tetrahymena thermophila by efficient degradation. Aquat. Toxicol. 149: 126-132.

35. Feng L, Wang G, Hamilton EP, Xiong J, Yan G, Chen K, et al. 
2017. A germline-limited piggyBac transposase gene is required for precise excision in Tetrahymena genome rearrangement. Nucleic Acids Res. 45: 9481-9502.

36. Kim JG, Yousef AE, Khadre MA. 2003. Ozone and its current and future application in the food industry. Adv. Food Nutr. Res. 45: 167-218.

37. Wilson WW, Wade MM, Holman SC, Champlin FR. 2001. Status of methods for assessing bacterial cell surface charge properties based on zeta potential measurements. J. Microbiol. Methods 43: 153-164.

38. Klodzinska E, Szumski M, Dziubakiewicz E, Hrynkiewicz K, Skwarek E, Janusz W, et al. 2010. Effect of zeta potential value on bacterial behavior during electrophoretic separation. Electrophoresis 31: 1590-1596.

39. Uchide N, Ohyama K, Bessho T, Toyoda H. 2009. Lactate dehydrogenase leakage as a marker for apoptotic cell degradation induced by influenza virus infection in human fetal membrane cells. Intervirology 52: 164-173.

40. Hunt NK, Mariñas BJ. 1999. Inactivation of Escherichia coli with ozone: chemical and inactivation kinetics. Water Res. 33: 2633-2641.

41. Kang SW. 2015. Superoxide dismutase 2 gene and cancer risk: evidence from an updated meta-analysis. Int. J. Clin. Exp. Med. 8: 14647-14655.
42. Bocci V. 2008. The question of balance: the interaction between blood and ozone, pp. 155-165. In Valacchi G, Davis P (eds.), Oxidants in Biology. Springer, Netherlands.

43. Clancy S. 2008. DNA damage \& repair: mechanisms for maintaining DNA integrity. Nat. Educ. 1: 103.

44. Zheng J, Su C, Zhou JW, Xu LK, Qian YY, Chen H. 2017. Effects and mechanisms of ultraviolet, chlorination, and ozone disinfection on antibiotic resistance genes in secondary effluents of municipal wastewater treatment plants. Chem. Eng. J. 317: 309-316.

45. Kuroda T, Tsuchiya T. 2009. Multidrug efflux transporters in the MATE family. Biochim. Biophys. Acta 1794: 763-768.

46. Jiménez-Arribas G, Léautaud V, Amábile-Cuevas CF. 2001. Regulatory locus soxRS partially protects Escherichia coli against ozone. FEMS Microbiol. Lett. 195: 175-177.

47. Laukens K, Naulaerts S, Berghe WV. 2015. Bioinformatics approaches for the functional interpretation of protein lists: from ontology term enrichment to network analysis. Proteomics 15: 981-996.

48. Conesa A, Gotz S, Garcia-Gomez JM, Terol J, Talon M, Robles M. 2005. Blast2GO: a universal tool for annotation, visualization and analysis in functional genomics research. Bioinformatics 21: 3674-3676. 